\title{
The aquatic species Pontederia azurea and P. crassipes (Pontederiaceae) in the Pantanal, Brazil: evidence of how plant structure can simultaneously reflect phylogeny and ecology
}

\author{
Thales D. Leandro ${ }^{1 *}$ (D), Zildamara dos Reis Holsback ${ }^{2}$ (1) and Edna Scremin-Dias ${ }^{3}$ (i)
}

Received: June 14, 2020

Accepted: November 4, 2020

\begin{abstract}
Hydric fluctuations in the Pantanal comprise annual dry and wet seasons that modify local diversity and plant morphology and anatomy. Widespread in this wetland are the sympatric Pontederia azurea and P. crassipes, which, although primarily aquatic, can also develop in non-flooded environments. This study undertook a comparative investigation of the qualitative and quantitative phenotypic responses and strategies of these two species (regarding life-form and leaf morpho-anatomy) in moderately dry and aquatic environments in the Pantanal. Field observations, conventional methods in plant anatomy, and leaf biometry were performed, followed by statistical analyses. Phenotypic responses, such as the decreased size of lacunae, increased lignification of vessel elements, and storage of starch granules, are the most prominent responses associated with moderately dry environments. The ability of petioles to elongate and inflate seems to be closely related to specific morphological patterns of each species. In contrast, petiole length, leaf blade dimensions, size of lacunae, and lignification rates seem to be somewhat associated with water level fluctuations. Our results provide evidence of how plant structure can simultaneously reflect phylogeny and ecology, thus supporting further investigations into phenotypic plasticity.
\end{abstract}

Keywords: anatomy, aquatic plants, Commelinales, drought resistance, ecology, morphology, wetlands

\section{Introduction}

In Central-Western Brazil, the Pantanal wetland exhibits a remarkable hydric fluctuation comprising dry and wet seasons, which seasonally modifies plant diversity (Pedralli 1992; Prado et al. 1994; Pott \& Pott 1997; 2000; Bao et al. 2018; Catian et al. 2018). In this sense, hydrological cycles characterize a fundamental environmental factor, influencing and modifying the floristic composition and morphology and anatomy of plants living in wetlands
(Blom et al. 1990; Bornette \& Amoros 1991; Henry et al. 1994; Scremin-Dias 2000a; 2009; Bornette et al. 2001, ScreminDias et al. 2011).

The ability that the same species has to develop in nonflooded (or exclusively terrestrial) and flooded (i.e., aquatic) environments is an inherent strategy of its survival and colonization in floodplains (Scremin-Dias 2000a). The occurrence of aquatic plants in non-flooded environments - which usually occurs when ponds and riverbeds dry out in the Pantanal - depends on their ability to respond (e.g., structurally and physiologically) hydric fluctuations. This

1 Departamento de Biodiversidade, Instituto de Biociências, Universidade Estadual Paulista, 13506-900, Rio Claro, SP, Brazil

2 Universidade Estadual de Mato Grosso do Sul, 79740-000, Ivinhema, MS, Brazil

3 Laboratório de Botânica, Instituto de Biociências, Universidade Federal de Mato Grosso do Sul, 79070-900, Campo Grande, MS, Brazil

* Corresponding author: thaleshdias@gmail.com 
ability is an environment-dependent phenotypic expression, generally referred to as phenotypic plasticity (Coleman et al. 1994; Sultan 2003). Our focus in this paper is not to address the intricate, genetic-based field of phenotypic plasticity. Instead, we focus on phenotypic responses to investigate qualitative and quantitative morpho-anatomical changes and strategies of aquatic species associated with seasonally dry environments in the Pantanal. This kind of approach is one of the first steps in providing relevant findings on phenotypic plasticity and understanding the evolutionary patterns and processes in plants (Sultan 1995; 2003).

Given the importance of the Pantanal wetland as an ecosystem and studies focused on understanding plant responses and strategies to hydric fluctuations in natural habitats, we studied two sympatric, aquatic species: Pontederia azurea and P. crassipes (both formerly placed within Eichhornia; see Pellegrini et al. 2018 for taxonomic history). Regionally referred to as aguapé, these monocots belong to the exclusively aquatic family Pontederiaceae (Commelinales) but can grow and thrive in seasonally non-flooded environments in this wetland. Phylogenetically, Pontederiaceae has been recognized as monophyletic with high statistical support and currently comprises two genera (Heteranthera Ruiz \& Pav. and Pontederia L.), being P. crassipes placed in the monospecific Pontederia subg. Oshunae and P. azurea placed in Pontederia subg. Eichhornia (Pellegrini et al. 2018).

Pontederia azurea and P. crassipes are widespread in the Pantanal (Pott \& Pott 2000; Pott et al. 2011; Aoki et al. 2017-listed under Eichhornia). Both species grow in damp to saturated soils during the dry season, presumably resulting in several structural changes in their vegetative organs. Leaf area, density and distribution of trichomes and stomata, development of aerenchyma, and lignification rates have been the most common structural changes observed in response to hydric fluctuations in this wetland (e.g., Scremin-Dias 1992; 1999; 2000a; 2000b; Bona \& Morretes 2003; Rodrigues et al. 2007; Scremin-Dias 2009; Catian \& Scremin-Dias 2015; Santana et al. 2019).

The goal of this study was to comparatively investigate qualitative and quantitative phenotypic responses and strategies of $P$. azurea and P. crassipes in moderately dry (i.e., non-flooded) and aquatic (i.e., flooded) environments in the Pantanal, regarding life-form and leaf (i.e., petiole and leaf blade). We hypothesize that phenotypic responses of the sympatric but not phylogenetically closely related species P. azurea and P. crassipes reflect the phylogeny and ecology of Pontederiaceae.

\section{Materials and methods}

\section{Study sites and sampling}

Sampling was carried out in a transitional zone that progressively dries in the course of the low water phase in the Pantanal. Two temporary ponds (i.e., site 1 and site 2) along the Miranda River, municipality of Corumbá, State of Mato Grosso do Sul, Brazil (Fig. 1), were chosen as the study sites. For both study sites, 50 sympatric specimens each of Pontederia azurea and $P$. crassipes were randomly sampled in September 2006 and 2007: (i) at the center of the temporary ponds (i.e., flooded environment, about $1 \mathrm{~m}$ water depth); and (ii) at the margin of the temporary ponds (i.e., non-flooded environment, wet soil). Sampling was carried out taking into account the clonal strategies of Pontederiaceae (see Barrett \& Graham 1997) to ensure that intraspecific variations were addressed. For both environments, two specimens of each species were housed in the Herbarium CGMS at Universidade Federal de Mato Grosso do Sul (UFMS), under voucher numbers 22.262 and 22.295 (P. azurea), and 30.640 and 31.256 (P. crassipes) —all registered as Eichhornia. Herbarium acronym follows Thiers (2020, continuously updated).

As a conceptual and terminological note, we did not consider non-flooded environments (i.e., damp, saturated, and seasonally flooded) as representing truly terrestrial environments. Based on field observations, plants living in these environments in the Pantanal generally endure seasonal flooding and regularly have to tolerate high soil humidity levels. Therefore, the terms "aquatic environment" and "moderately dry environment" were respectively used as proxies for the flooded and non-flooded environments herein studied.

\section{Qualitative analysis (anatomy and histochemistry)}

Light microscopy (LM). For each species, mature leaves (i.e., leaf blades and petioles) of five specimens were taken from the third or fourth stem node and fixed in FAA50 for 48 hours (Johansen 1940). Samples were then washed three times within two hours in distilled water and stored in $70 \%$ ethanol. Each sample was dehydrated through a graded n-butyl series and embedded in glycol methacrylate (Leica Historesin Embedding Kit) following conventional methods. Cross-sections were made in the middle portion of leaf blades and petioles with the aid of a rotary microtome Leica RM $2145(5 \mu \mathrm{m})$ and free-handed. Sections were stained with Alcian Blue and Basic Fuchsin (Luque et al. 1996) or $0.05 \%$ Toluidine blue with pH 4.7 (O’Brien et al. 1964). Histochemical analyses were performed using free-handed cross-sections. The presence of starch granules and phenolic compounds were tested with iodine and ferric chloride reactions, respectively (Johansen 1940). Tests with acetic acid and hydrochloric acid were carried out to confirm the nature of crystals (Johansen 1940). Photomicrographs were obtained using a Leica DM 5500B microscope through the Leica Application Suite LASV3.8. at the Laboratório de Botânica, UFMS.

Scanning electron microscopy (SEM). To describe some qualitative aspects in detail (e.g., shape of crystals), pieces of approximately $1 \mathrm{~cm}^{2}$ from the middle portion of leaf blades were dehydrated through a graded n-butyl series 
and dried using the critical point drying method (Bray 2000) (Quorum Technologies CPD 7501). Dried samples were vertically attached to a cylindrical sample holder (i.e., stub), and then coated with a thin layer of gold (Denton vacuum Desk III). Photomicrographs were captured with a DSM 940 Carl Zeiss scanning electron microscope at the Centro de Aquisição de Imagens e Microscopia do Instituto de Biociências - CAIMi/IB, Universidade de São Paulo (USP).

\section{Quantitative structural analysis (morpho-anatomy and} statistics)

For quantitative analyses, 50 mature leaves of each species from both environments (i.e., aquatic and moderately dry) were analyzed. The length and diameter of petioles and length and width of leaf blades were measured using a digital caliper and ruler. The height of epidermal cells of leaf blades and petioles were also measured, and the mesophyll thickness of leaf blades. Anatomical measurements were performed through the Leica Application Suite LASV3.8 using photomicrographs obtained from LM techniques.

We regarded plants from aquatic environments $(n=50)$ and moderately dry environments $(n=50)$ as fixed variables. An ANOVA One-Way model for each species was built to determine the environmental influence on biometric data. In this model, the data were standardized using zero mean and unit variances. When needed, we used Tukey's test for
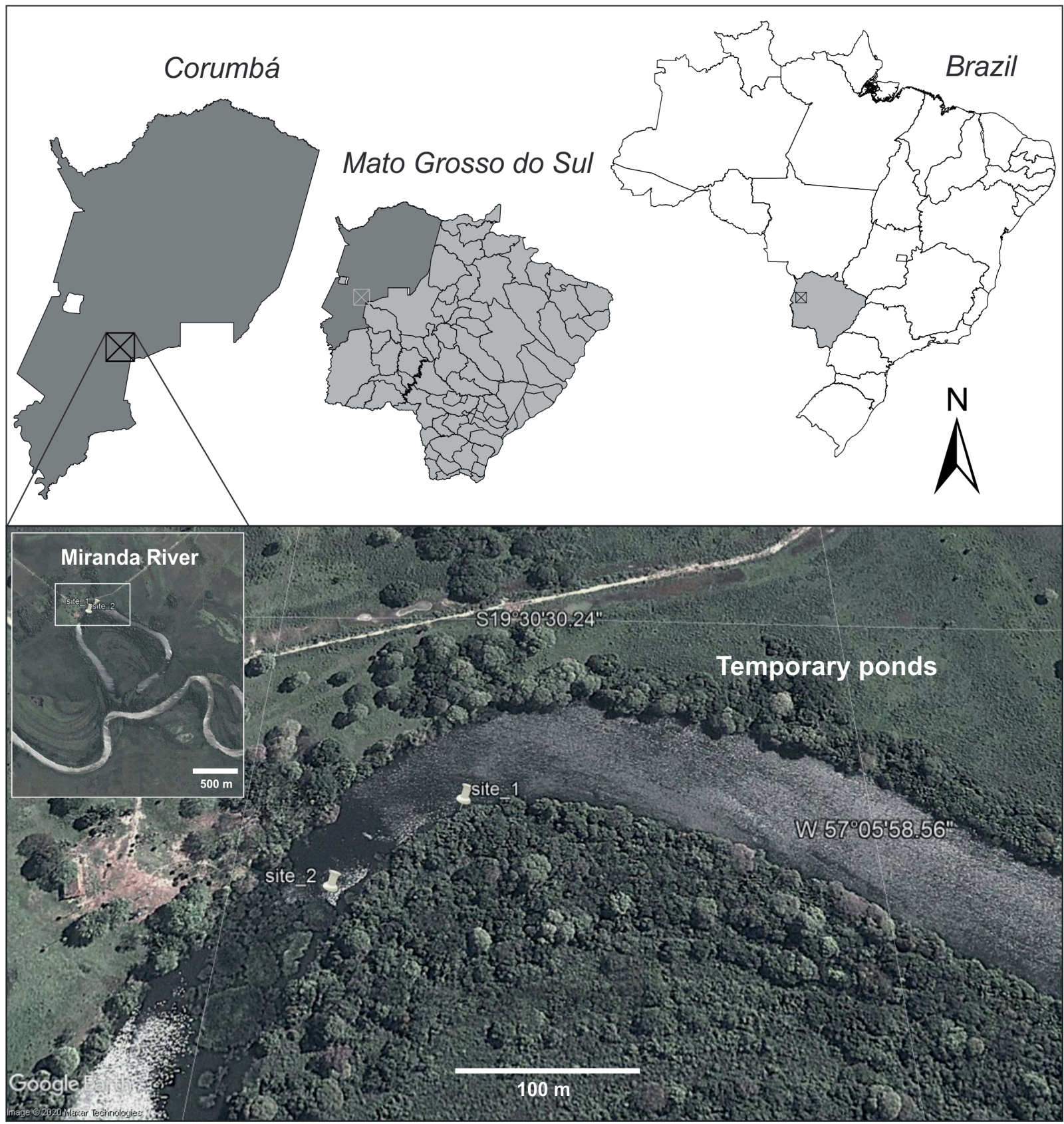

Figure 1. Location of the two study sites in the Pantanal, Corumbá, State of Mato Grosso do Sul, Brazil. Source: Google Earth Pro (2019). 
post-hoc comparisons. Statistical analyses were performed using the SigmaStat 4.0 software (Systat Sofware Inc., San Jose, CA) for Windows. Finally, we graphically present the biometric data to provide an evident representation of the results.

\section{Results}

\section{Life-forms and quantitative data (anatomy and morphology of leaf blades and petioles)}

Pontederia azurea is permanently rooted in the substrate in both aquatic and moderately dry environments (Fig. 2A-B), transitioning from a rooted-floating plant to a procumbent emergent or paludal plant. Nonetheless, plants from aquatic environments exhibit a more significant increase in petiole length (Figs. 2B; 3). There are no significant differences, however, in the diameter of petioles (Fig. 3A), the length and width of leaf blades (Fig. 3B), and the height of epidermal cells (Fig. 3D) between plants from aquatic and moderately dry environments. In contrast, the mesophyll thickness of $P$. azurea increases in plants from moderately dry environments (Fig. $3 C$ ).

Pontederia crassipes is rooted in the substrate in moderately dry environments (i.e., procumbent emergent plants) (Fig. 2C), but truly free-floating plants occur in aquatic environments (Fig. 2D). Pontederia crassipes exhibits a significant increase in the length and diameter of its petioles (Fig. 3A) as they become inflated (Fig. 2E, left), with large rotund leaves in aquatic environments. The leaf blade anatomical measurements of aquatic plants show greater mesophyll thickness (Fig. 3C). We can also observe statistical differences in the height of the petiole epidermal cells when comparing plants from both environments (Fig. 3D).

\section{Qualitative data (anatomy of leaf blades and petioles)}

The comparative analysis of the leaf anatomy of $P$. azurea and $P$. crassipes regarding aquatic and moderately dry environments are shown in Figures 4A-H, 5A-J, 6A-F. Data obtained from LM and SEM are merged to provide a better understanding of the description. The description of petioles only highlights features worth mentioning compared to leaf blades.

\section{Leaf blades}

Both species exhibit a single layer of epidermal cells with thin cell walls (Fig. 4A-H). Epidermal cells are anticlinally more elongated in leaf blades from aquatic environments in P. crassipes (Fig. 4H). On the other hand, P. azurea does not exhibit differences regarding the height of epidermal cells (Fig. 4B, D) - see also quantitative data for both species in Figure 2D. Leaves are amphistomatic in both species (Fig. 4A-H).
The mesophyll of both species is heterogeneous and comprises parenchyma cells (i.e., chlorenchyma and aerenchyma), with thin cell walls (Fig. 4A, C, E, G). The chlorenchyma comprises three to four layers of palisade cells adjacent to the upper and lower leaf blade surfaces in P. azurea (Fig. 4B, D) and two to three layers adjacent to the upper surface in P. crassipes (Fig. 4F, H). Adjacent to the lower surface of $P$. crassipes, the palisade-shaped parenchyma cells are replaced by spongy parenchyma (Fig. 4E, G). Palisade cells in P. azurea are mostly compact in cross-section (Fig. 4A, C-D), whereas $P$. crassipes exhibits many intercellular spaces (Fig. 4E-G). Aquatic plants of both species exhibit well-developed aerenchyma with wide lacunae (Fig. 4C, G), but no differences are remarkably discernible between plants from aquatic and moderately dry environments (Fig. 4A, C, E, G). Regarding the aerenchyma, lacunae are delimited by spongy parenchyma in P. crassipes (Fig. 4E-H), whereas irregular-shaped parenchyma cells delimit the lacunae in P. azurea (Fig. 4A, C). Diaphragms mostly comprised of stellate cells are observed in the aerenchyma of both species. However, they are more frequent in aquatic plants and leaf blades of $P$. azurea regardless of the environment (Figs. 4A, C). Aside from stellate cells, round-shaped cells can also occur comprising the diaphragms (Fig. 6B). Idioblasts containing crystals (see next subsection) and phenolic compounds (Fig. 4A-G) are also observed.

Collateral vascular bundles surrounded by a double sheath occur mostly in the central portion of the leaf blade in P. crassipes (Fig. 4E, G) and adjacent to the epidermis of both surfaces in P. azurea (Fig. 4A, C). Vascular bundles exhibit xylem abaxially oriented (Fig. 4A-C, E, G-H). Vessel elements are thicker and lignified in plants from moderately dry environments (Fig. 4B, F). Starch granules may be observed in bundle sheath cells, usually more evident in plants in moderately dry environments (data not shown).

Petioles

The petiole anatomy of both species is quite similar regarding the leaf blade, in that they share: (i) single-layered epidermis, with thin cell walls (Fig. 5A-D); (ii) isodiametric parenchyma cells (i.e., chlorenchyma) adjacent to the epidermis (Fig. 5A-C), followed by aerenchyma comprising several lacunae delimited solely by isodiametric cells (Fig. $5 \mathrm{~A}-\mathrm{C}, \mathrm{E}, \mathrm{H}$ ); and (iii) collateral vascular bundles surrounded by a double sheath (e.g., Fig. 5B, F-G).

Plants of both species occurring in aquatic environments exhibit well-developed aerenchyma (Fig. 5C, D, H). Diaphragms mostly comprised of stellate cells are also observed in the aerenchyma of both species regardless of the environment (Figs. 5A, C, H; 6A, D, F), although they are more frequent in aquatic plants and petioles of $P$. azurea (Figs. 5A, C; 6B, D). Aside from the stellate cells, diaphragms of $P$. crassipes may exhibit round-shaped cells (e.g., 5I) and irregular-shaped cells with no intercellular spaces (e.g., Fig. 5J) in moderately dry and aquatic environments, respectively. 

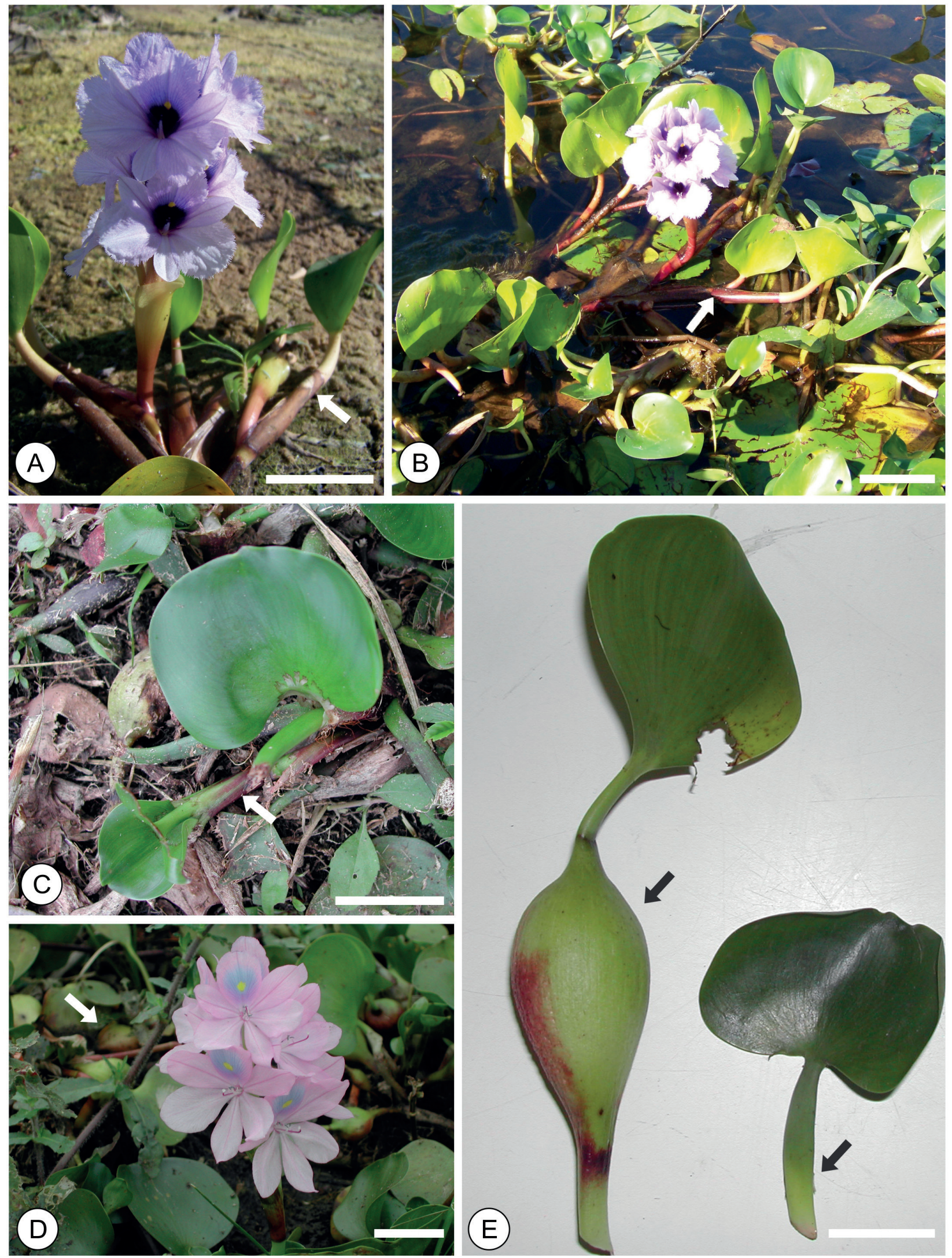

Figure 2. Life-forms of the studied species. A-B Pontederia azurea. C-E Pontederia crassipes. A and C. Moderately dry environments, with damp soil. B and D. Aquatic environments. E. Morphological comparison of leaves (leaf blades and petioles) in aquatic (left) and moderately dry (right) environments. Scale bars $=3 \mathrm{~cm}(\mathbf{A}-\mathbf{B}$ and $\mathbf{E}) ; 2 \mathrm{~cm}(\mathbf{C}-\mathbf{D})=2 \mathrm{~cm}$. Arrows = petioles. 
Idioblasts containing styloid crystals and phenolic compounds are observed crossing the diaphragms (Fig. $6 C, E-F)$. Plants of both species from moderately dry environments exhibit an elevated amount of starch granules in their vascular bundle sheaths and diaphragms (e.g., Fig. $5 \mathrm{~F}, \mathrm{I})$. Collateral vascular bundles surrounded by a double sheath are arranged in two to three concentric rings adjacent to the epidermis (Fig. 5A, C). Vascular bundles exhibit vessel elements (i.e., xylem) with thicker and lignified cell walls in plants from moderately dry environments (Fig. 5A, F).

\section{Discussion}

\section{Life-forms and leaf morphology}

As observed during fieldwork, P. azurea is permanently rooted in the soil regardless of the environment, transitioning from a rooted-floating plant to a procumbent emergent or paludal plant. Alternatively, P. crassipes is procumbent emergent, rooted in the soil only if plants are growing in moderately dry environments, becoming free-floating along with the rising water levels during floods in the
Pantanal. Although both species are regarded as aquatic plants, local hydric fluctuations likely play a selective role, driving switches between the two $P$. crassipes life-forms (i.e., procumbent emergent to free-floating), as well as several structural changes in both species.

When ponds and riverbeds start to dry out in the Pantanal, besides seed germination and seedling establishment in saturated soils, free-floating individuals of $P$. crassipes may become rooted in the soil. However, clonal integration between these previously aquatic individuals remains via stolons. Apparently, such strategies increase the colonization success rate of $P$. crassipes in transitional and non-flooded zones in the Pantanal (pers. observ.). This assumption is supported by a simulation study, which has proved that clonal integration increases growth performance and expansion of P. crassipes in littoral zones (Yu et al. 2019).

Vegetative propagation of the rooted-floating P. azurea can also occur by stolons, but its propagation is mainly by stem fragmentation. It is well known that the dispersal of vegetative structures (i.e., stolons and fragmented stems) by water allows colonization of new environments by Pontederiaceae species (Barrett \& Graham 1997). While the clonal strategies of $P$. azurea and $P$. crassipes seem to
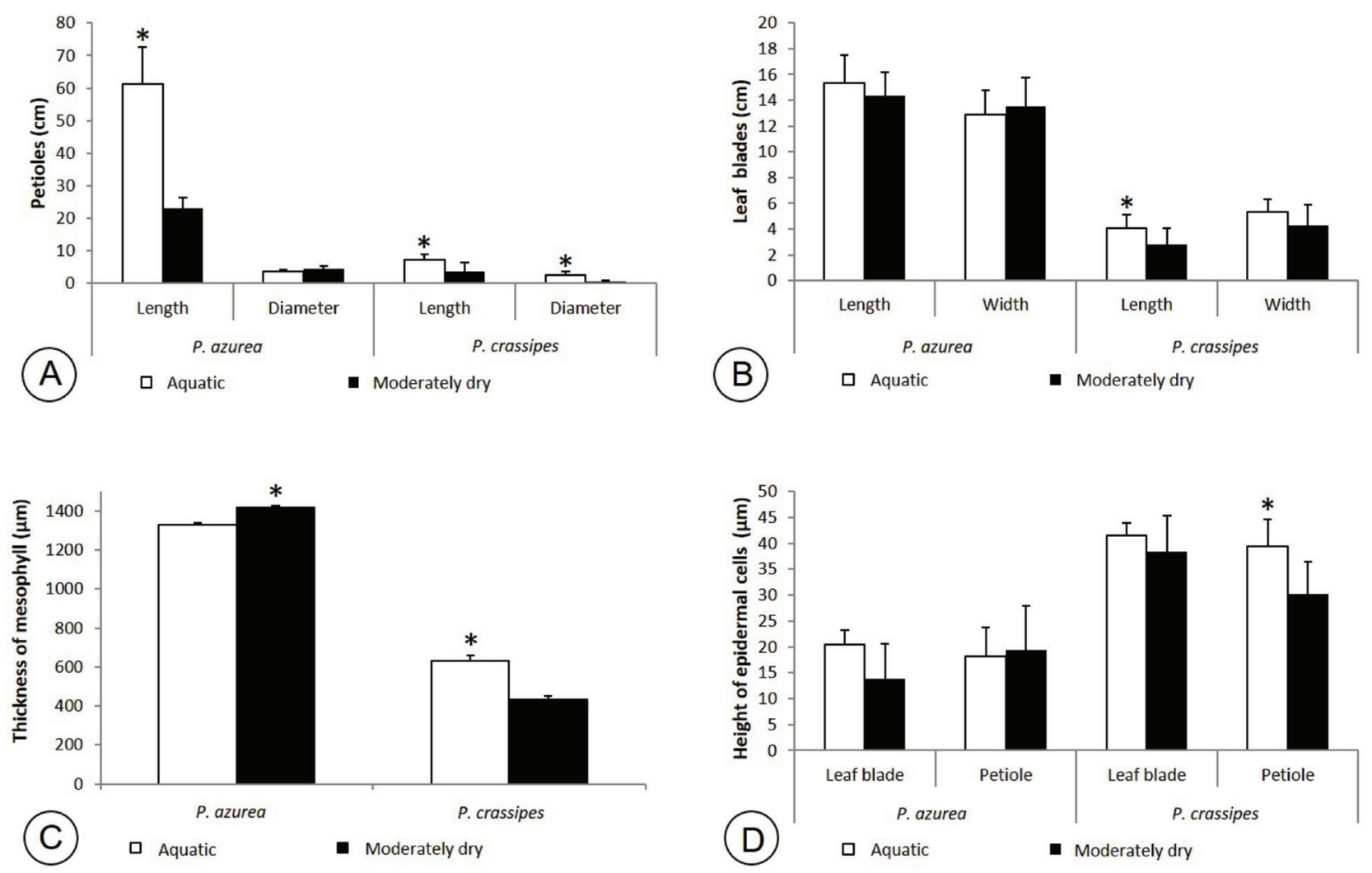

Figure 3. Graphical representation of morpho-anatomical parameters of Pontederia azurea and P. crassipes in aquatic and moderately dry environments. A. Length and diameter of petioles in centimeters $(\mathrm{cm})$ : mean length in $P$. azurea $(\mathrm{t}=2.08, \mathrm{p}<0.05, \mathrm{n}=50) ; \mathrm{mean}$ length in P. crassipes ( $\mathrm{t}=1.76, \mathrm{p}<0.05, \mathrm{n}=50)$; and mean diameter in P. crassipes $(\mathrm{t}=2.25, \mathrm{p}<0.05, \mathrm{n}=50)$. B. Length and width of leaf blades in centimeters $(\mathrm{cm})$ : mean length in P. crassipes $(\mathrm{t}=2.13, \mathrm{p}<0.05, \mathrm{n}=50)$. C. Thickness of the mesophyll in micrometers $(\mu \mathrm{m})$ : mean thickness in P. azurea ( $\mathrm{t}=50.84, \mathrm{p}<0.05, \mathrm{n}=50)$; mean of thickness in P. crassipes $(\mathrm{t}=50.83, \mathrm{p}<0.05, \mathrm{n}=50)$. D. Height (anticlinal width) of epidermal cells in micrometers $(\mu \mathrm{m})$ : mean height in . crassipes $(\mathrm{t}=4.34, \mathrm{p}<0.05, \mathrm{n}=50)$. ${ }^{*}$ indicates statistical significance. 

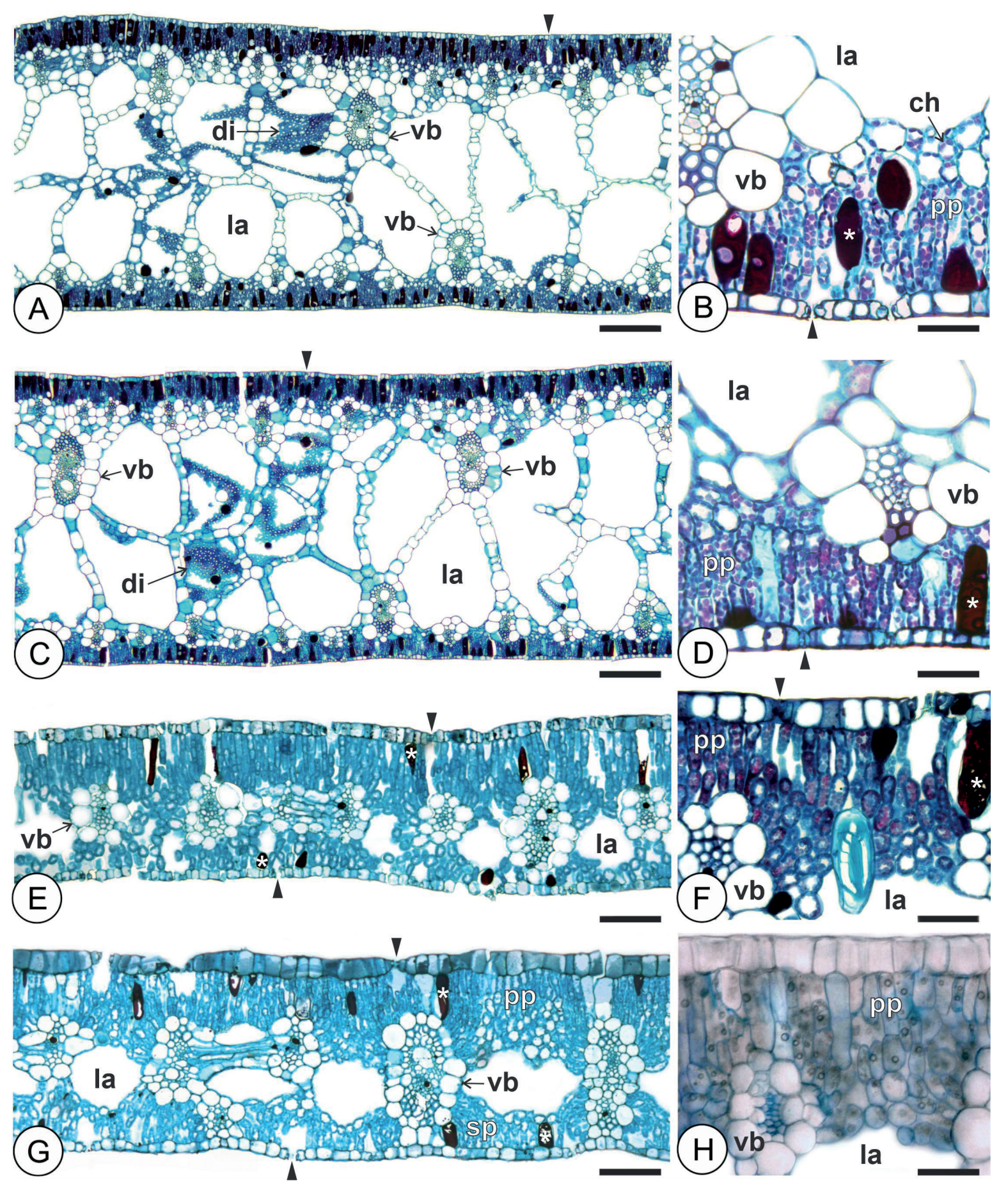

Figure 4. Leaf blade anatomy in cross-section (LM). A-D Pontederia azurea. E-H Pontederia crassipes. A. Specimen from a moderately dry environment showing mesophyll comprising palisade parenchyma adjacent to the upper and lower surfaces, and aerenchyma with diaphragms. B. Specimen from a moderately dry environment showing epidermal cells, palisade cells, and idioblast with phenolic compounds. C. Specimen from an aquatic environment showing mesophyll comprising palisade parenchyma adjacent to the upper and lower surfaces; and aerenchyma, with diaphragms. D. Specimen from an aquatic environment showing epidermal cells, palisade cells, collateral vascular bundle, and idioblasts with phenolic compounds. E. Specimen from a moderately dry environment showing mesophyll comprising palisade parenchyma adjacent to the upper surface, spongy parenchyma, and aerenchyma. F. Specimen from a moderately dry environment showing epidermal cells, palisade cells, collateral vascular bundle, and idioblasts with phenolic compounds. G. Specimen from an aquatic environment showing mesophyll comprising palisade parenchyma adjacent to the upper surface, spongy parenchyma, and aerenchyma. H. Specimen from an aquatic environment showing epidermal cells, palisade cells, collateral vascular bundle, and idioblasts with phenolic compounds. ae: aerenchyma. ch: chloroplasts. di: diaphragm. la: lacuna. sp: spongy parenchyma. vb: vascular bundle. Arrowheads = stoma. Asterisks = idioblast with phenolic compounds. Scale bars $=25 \mu \mathrm{m}(\mathbf{B}, \mathbf{D}, \mathbf{F}, \mathbf{H}) ; 50 \mu \mathrm{m}(\mathbf{A}, \mathbf{C}, \mathbf{E}, \mathbf{G})$. 

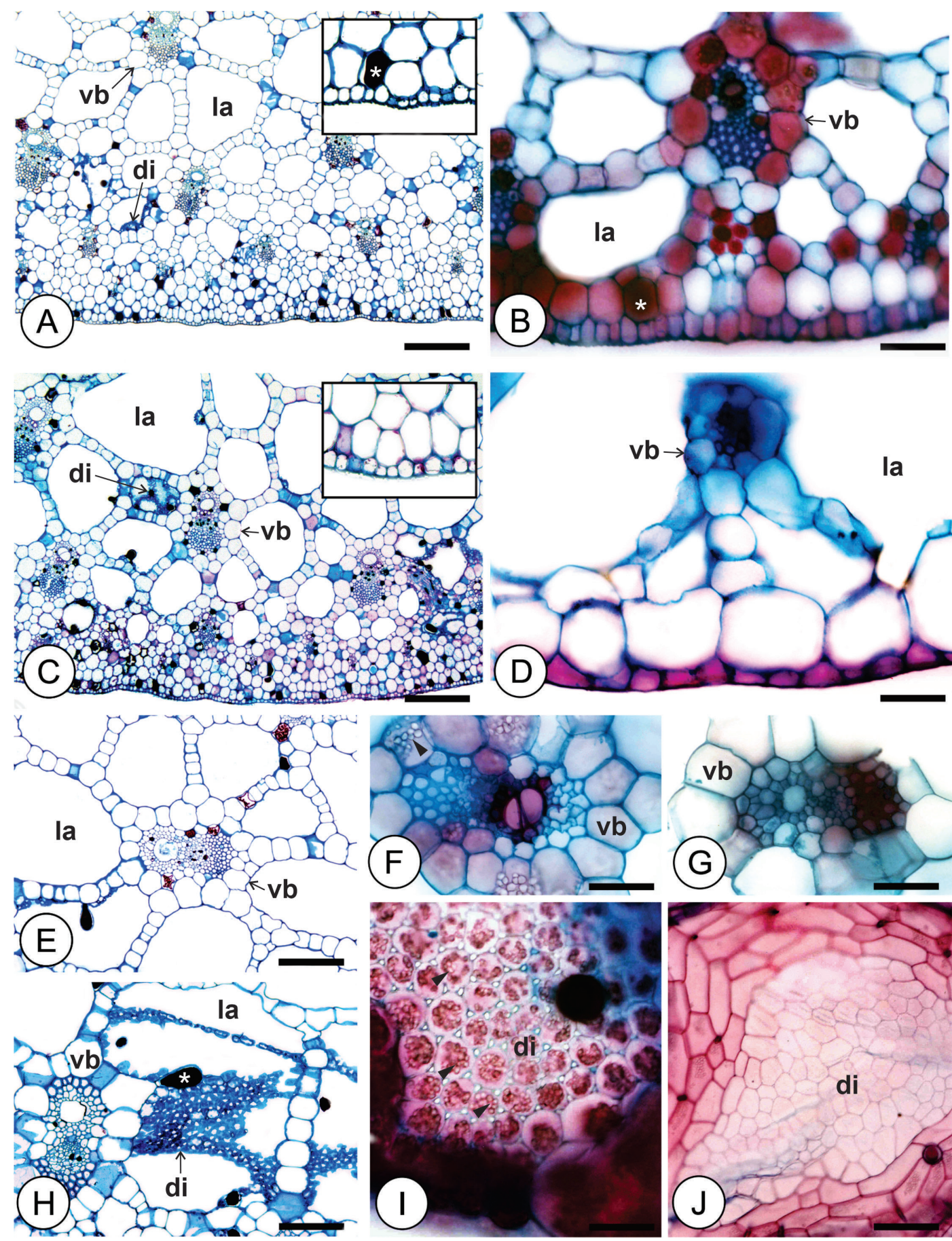

Figure 5. Petiole anatomy in cross-section (LM). A, C, E, H Pontederia azurea. B, D, F-G, I-J Pontederia crassipes. A. Specimen from a moderately dry environment showing aerenchyma, idioblasts with phenolic compounds, and epidermal cells (inset). B. Specimen from a moderately dry environment showing epidermal cells, aerenchyma, collateral vascular bundle, and idioblasts with phenolic compounds. C. Specimen from an aquatic environment showing aerenchyma, idioblasts with phenolic compounds, and epidermal cells (inset). D. Specimen from an aquatic environment showing epidermal cells, aerenchyma, collateral vascular bundle, and idioblasts with phenolic compounds. E. Specimen from a moderately dry environment showing aerenchyma, collateral vascular bundle, and idioblasts with phenolic compounds. F. Specimen from a moderately dry environment showing aerenchyma, well-lignified vessel elements comprising the vascular bundle, and starch granules. G. Specimen from an aquatic environment showing less lignified vessel elements comprising the vascular bundle. H. Specimen from an aquatic environment showing aerenchyma with diaphragms comprised of stellate cells, collateral vascular bundle, and idioblasts with phenolic compounds. I. Specimen from a moderately dry environment showing diaphragms comprised of round-shaped cells with a high amount of starch granules. J. Diaphragms of a specimen from an aquatic environment showing irregular-shaped cells. ae: aerenchyma. di: diaphragm. la: lacuna. vb: vascular bundle. Arrowheads = starch granules. Asterisks = idioblast with phenolic compounds. Scale bars = $6 \mu \mathrm{m}(\mathbf{D}) ; 12 \mu \mathrm{m}(\mathbf{B}, \mathbf{F}-\mathbf{G}) ; 25(\mathbf{E}, \mathbf{H}, \mathbf{I}-\mathbf{J}) ; 50 \mu \mathrm{m}(\mathbf{A}, \mathbf{C})$. 

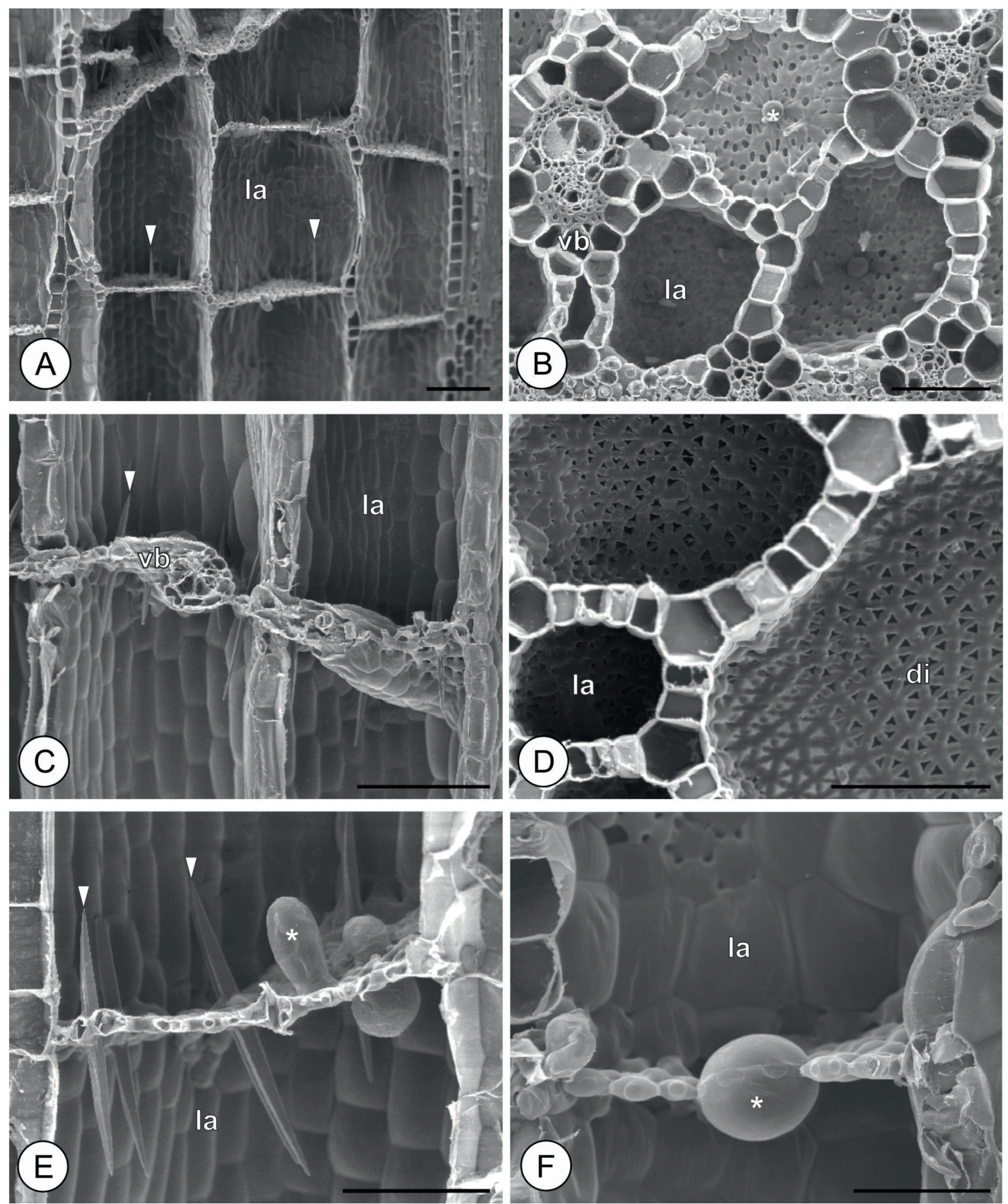

Figure 6. SEM images of leaves (leaf blade and petioles). A Pontederia crassipes. B-F Pontederia azurea. A. Petiole in longitudinal view showing aerenchyma (lacunae), with diaphragms and idioblasts with styloid crystals. B. Leaf blade in cross-section showing vascular bundles, aerenchyma with diaphragms comprised of round-shaped cells. C. Petiole in longitudinal view showing a vascular bundle crossing the lacunae (aerenchyma) and idioblasts with styloid crystals. D. Petiole in cross-section showing aerenchyma with diaphragms comprised of stellate cells. E. Petiole in longitudinal view showing diaphragms with idioblasts and styloid crystals. F. Petiole in longitudinal view showing a diaphragm with an idioblast with phenolic compounds. di: diaphragm. la: lacuna. vb: vascular bundle. Arrowheads = idioblast with styloid crystals. Asterisks = idioblast with phenolic compounds. Scale bars $=400 \mu \mathrm{m}(\mathbf{A}, \mathbf{B})$; $90 \mu \mathrm{m}$ (C); $105 \mu \mathrm{m}$ (D); $150 \mu \mathrm{m}$ (E-F). 
be somehow related to their life-forms, it is likely that clonality and life-form play a role to successfully increase the colonization rates of both species in the Pantanal. This seems to be particularly true for the free-floating $P$. crassipes.

During floods in the Pantanal, one of the most common responses of plants rooted in the soil is the elongation of stems and petioles to elevate leaf blades and reproductive structures above the water (Scremin-Dias et al. 1999; 2011; Scremin-Dias 2000a; 2000b; 2009). A similar response is also observed in $P$. azurea, which exhibits long petioles regardless of the environment and increases, even more, the length of its stems and petioles in wet seasons. Pontederia crassipes, in contrast, usually exhibits short internodes even in aquatic environments, with slight and occasional elongation of stems, petioles, and leaf blades - which seems to be somewhat associated with a light competition strategy of dense mats (see Center \& Spencer 1981; Richards \& Lee 1986; Gruntman et al. 2017). In the present study, the distinct morphology and strategies observed in P. azurea and $P$. crassipes support the evidence that morphological patterns within Pontederiaceae are influenced by changes in the environment and the result of independent origins within the family (Barrett \& Graham 1997; Pellegrini et al. 2018).

The free-floating life-form and inflated petioles of $P$. crassipes are unique within Pontederiaceae (Sousa et al. 2016; Pellegrini et al. 2018). Since the emergent life-form has been recognized as plesiomorphic within the family (Barrett \& Graham 1997) and P. crassipes is currently the only species placed in the Pontederia subg. Oshunae (Pellegrini et al. 2018), the free-floating life-form and inflated petioles have been interpreted as autapomorphies within Pontederiaceae (Pellegrini et al. 2018). Although the emergent life-form seems to be the precursor of other life-forms within the family (Barrett \& Graham 1997) and the inflated petiole of $P$. crassipes is a great response that allows individuals to float, further investigations are needed to clarify the influence of water as a selective pressure driving the origin and evolution of life-forms in Pontederiaceae.

\section{Leaf anatomy}

Aside from morphological synapomorphies (see Pellegrini et al. 2018), P. azurea and P. crassipes also share leaf anatomical synapomorphies with other Pontederiaceae, such as the central portion of leaf blades with alternate xylem and phloem, and abaxially oriented xylem (Arber 1925; Pellegrini et al. 2018). In contrast, the most prominent responses associated with moderately dry environments observed in the present study are: (i) an apparent decrease in the size of lacunae (i.e., aerenchyma); (ii) the increased lignification of vessel elements (i.e., xylem); and (iii) the storage of starch granules.

Lacunae are observed in leaf blades and petioles of both species, regardless of the environment. However, as expected, the size of the lacunae is most prominent in plants occurring in aquatic environments regardless of the species, as previously observed in many other aquatic plants in the Pantanal (Scremin-Dias 2000a; 2000b; 2009; Scremin-Dias et al. 2011). Also, lacunae are expected in the leaves of plants in moderately dry environments due to some permanent moisture content in the soil, which is common even several months after the last flood event in the Pantanal. Lacunae in plant tissues are often associated with aeration of organs and improvement of longitudinal oxygen transportation from photosynthetic areal parts (Pannier 1960; Sculthorpe 1967; Justin \& Armstrong 1987; Blom et al. 1990). Since the aquatic specimens sampled for the present study grew in temporary ponds (i.e., lentic ecosystems), we can assume that a small concentration of dissolved oxygen in the water might cause the remarkable size of the lacunae. Such interpretation may be supported by differences in the percentage of lacunae in Bacopa spp. (Plantaginaceae) between lentic and lotic environments in the Pantanal (Bona \& Morretes 2003). Further studies measuring the dissolved oxygen in temporary ponds and saturated soils would help interpret aerenchyma formation in the leaves of $P$. azurea and $P$. crassipes.

The mesophyll of $P$. azurea and P. crassipes is heterogeneous, regardless of the environment. We do not observe differences regarding the mesophyll structure (i.e., type and topography of the parenchyma) within the same species. It suggests that the mesophyll structure of both species is conservative and not influenced by hydric fluctuations. However, it is worth mentioning that the mesophyll structure has been previously associated with an increased contact between plant and water, in which emergent, floating, and submerged life-forms are accompanied by heterogeneous isolateral, heterogeneous dorsiventral, and homogeneous mesostructures, respectively (Ronzhina \& P'yankov 2001). Such correlation is also, curiously, observed by us in $P$. azurea (emergent plant $\leftrightarrow$ heterogeneous isolateral-like mesostructure) and $P$. crassipes (floating plant $\leftrightarrow$ heterogeneous dorsiventral-like mesostructure). Nonetheless, the adaxial-abaxial polarity (i.e., the distinction between adaxial and abaxial leaf blade surfaces or sides) in Pontederiaceae is not completely understood to date. Also, the odd arrangement of vascular bundles has been assumed as resulting from the reversion from abaxialized unifacial leaves in its closely related families (i.e., Haemodoraceae and Philydraceae-Simpson 1990; 1998; Hamann 1998) to bifacial leaves in Pontederiaceae (Pellegrini et al. 2018). According to Simpson (1990), such characteristics might be related to adaptive strategies and radiation to the aquatic lifestyle of Pontederiaceae species. Further developmental and functional studies are needed to elucidate the leaf polarity hypothesis and the potential relationship between water and mesophyll arrangement in the family. 
Leaves of $P$. azurea and $P$. crassipes sampled in moderately dry environments exhibit vessel elements with thick and lignified cell walls, mainly in the petioles. In general, lignification is a dynamic, physiological process resulting in structural rigidity of plant cells and tissues (Bonawitz \& Chapple 2010; Malavasi et al. 2016). In this context, the lignified and thick vessel elements observed in both studied species may provide, along with fluid conduction, mechanical support to leaves of plants occurring in moderately dry environments (Scremin-Dias 1992; Gordon \& Olson 1994; Myburg et al. 2013). Aquatic plants of $P$. azurea and P. crassipes, in contrast, presumably do not need much investment in lignification since water provides mechanical support required by submerged and floating parts. Lignification of cells and tissues may also contribute to the upright position of petioles regardless of the environment, exposing leaf blades to environmental light and keeping them out of the water. Although tissue lignification of both species supports their aerial structures (e.g., leaves and inflorescence main axis), field observations suggest that the lignification rates are sufficient to allow leaf flexibility and increase the length of these structures. Further comparative studies on the lignification rates and biomechanics of $P$. azurea and $P$. crassipes in both environments and at different water levels would allow more accurate conclusions.

The large amount of starch granules observed in the petioles of $P$. azurea and P. crassipes is another remarkable response associated with moderately dry environments. A study of Ludwigia sedoides (Onagraceae) has reported that one of the main anatomical differences between plants from aquatic and moderately dry environments is many starch granules in the vegetative organs of nonflooded plants (Scremin-Dias 1992). Similar responses have been reported in Echinodorus paniculatus and E. tenellus (Alismataceae), which lose their aerial parts and store a high amount of starch granules in their roots during events of drought in the Pantanal (Scremin-Dias 2000a; 2000b). Although not experimentally tested, the author suggested that Echinodorus plants mobilize starch stored during a dry season to develop new aerial parts during the next flood season. Since starch mobilization processes are not addressed in this paper, we cannot conclude the subject. However, we highlight the need for experimentallybased studies on starch biosynthesis and degradation in Pontederiaceae and other aquatic plants.

\section{Conclusions}

Primarily aquatic, the sympatric species $P$. azurea and $P$. crassipes exhibit distinct phenotypic responses in the Pantanal wetland. Responses such as the ability to elongate and inflate petioles are somewhat a result of their characteristic morphology, which in turn seems to be closely associated with aquatic habitats and life-forms evolved during the evolution of Pontederiaceae (Barrett
\& Graham 1997; Sousa et al. 2016; Pellegrini et al. 2018). In contrast, petiole length, leaf blade dimensions, size of lacunae, and lignification of vessel elements seem to be associated - but not solely - with fluctuations in the water level, as previously suggested for many aquatic species occurring in the Pantanal (see citations throughout this paper).

The congeneric Pontederia azurea and P. crassipes are not phylogenetically closely related to each other, being placed in distinct subgenera (Pellegrini et al. 2018). They repeatedly share some morpho-anatomical responses regardless of the environment, such as the presence of aerenchyma and storage of starch granules, which provides evidence that these phenotypic convergences are somehow adaptive (see Givnish 1997). Adaptation seems an even more appealing hypothesis since some of these convergences have also been reported in many other primarily aquatic and phylogenetically unrelated species occurring in the Pantanal (e.g., Scremin-Dias 1992; 2000a; 2000b; 2009; Scremin-Dias et al. 2011). Hence, the morpho-anatomical convergences of $P$. azurea and $P$. crassipes represent a promising field of investigation on phenotypic plasticity. Furthermore, phenotypic plasticity studies would help accurately understand the distinct and sometimes statistically significant morpho-anatomical differences observed (e.g., leaf blade mesophyll thickness and the height of petiole epidermal cells herein shown). Such studies would allow us to distinguish whether these phenotypic responses are functionally adaptive or developmentally inevitable.

The phenotypic responses observed in the present study provide evidence of how plant structure can simultaneously reflect phylogeny and ecology. Further functional, comparative, and population studies are needed to provide insights into adaptation and why certain features are adaptive or not.

\section{Acknowledgements}

The authors would like to thank APT Pereira for the P. azurea habit photographs, DCL Kufner for providing the biometric data of P. azurea, and AP Pinho for fieldwork assistance. The authors are thankful to the Centro de Aquisição de Imagens e Microscopia do Instituto de Biociências - CAIMi/IB at Universidade de São Paulo (USP) and the Base de Estudos do Pantanal (BEP/PROPP) staff at Universidade Federal de Mato Grosso do Sul (UFMS) for their assistance with SEM images and fieldwork.

\section{References}

Aoki C, Teixeira-Gamarra MC, Gamarra RM, et al. 2017. Abiotic factors drive the structure of aquatic plant assemblages in riverine habitats of the Brazilian “Pantanal”. Brazilian Journal of Botany 40: 405-415. 


\section{Thales D. Leandro, Zildamara dos Reis Holsback and Edna Scremin-Dias}

Arber A. 1925. Monocotyledons: A morphological study. Cambridge, University Press, Cambridge.

Bao F, Leandro TD, Rocha M da, et al. 2018. Plant species diversity in a Neotropical wetland: patterns of similarity; effects of distance, and altitude. Academia Brasileira de Ciências 90: 85-97.

Barrett SCH, Graham SW. 1997. Adaptive radiation in the aquatic plant family Pontederiaceae: insights from phylogenetic analysis. In: Givnish TJ, Sytsma KJ (eds.) Molecular evolution and adaptive radiation. Cambridge, Cambridge University Press. p. 225-258.

Blom CWPM, Bögemann GM, Laan P, et al. 1990. Adaptations to flooding in plants from river areas. Aquatic Botany 38: 29-47.

Bona C, Morretes BL. 2003. Anatomia das raízes de Bacopa salzmanii (Benth.) Wettst. ex Edwall e Bacopa monnierioides (Cham.) Robinson (Scrophulariaceae) em ambientes aquático e terrestre. Acta Botanica Brasilica 17: 155-170.

Bonawitz ND, Chapple C. 2010. The genetics of lignin biosynthesis: Connecting genotype to phenotype. Annual Review of Genetics 44: 337-63.

Bornette G, Amoros C. 1991. Aquatic vegetation and hydrology of a braided river floodplain. Journal of Vegetation Science 2: 497-512.

Bornette G, Piegay H, Citterio A, Amoros C, Godreau V. 2001. Aquatic plant diversity in four river floodplains: a comparison at two hierarchical levels. Biodiversity Conservation 10: 1683-1701.

Bray D. 2000. Critical point drying of biological specimens for scanning electron microscopy. In: Williams JR, Clifford AA. (eds.) Supercritical fluid methods and protocols. Methods in Biotechnology 13. New Jersey, Humana Press. p. 235-243.

Catian G, Silva DM, Súarez YR, Scremin-Dias E. 2018. Effects of flood pulse dynamics on functional diversity of macrophyte communities in the Pantanal wetland. Wetlands 38: 975-991.

Catian G, Scremin-Dias E. 2015. Phenotypic variations in leaf anatomy of Nymphaea gardneriana (Nymphaeaceae) demonstrate its adaptive plasticity. Journal of the Torrey Botanical Society 142: 18-26.

Center TD, Spencer NR. 1981. The phenology and growth of the water hyacinth (Eichhornia crassipes (Mart.) Solms.) in a eutrophic northcentral Florida lake. Aquatic Botany 10: 1-32.

Coleman JS, McConnaughay KDM, Ackerly DD. 1994. Interpreting phenotypic variation in plants. Tree 9: 187-191.

Givnish TJ. 1997. Adaptive radiation and molecular systematics: issues and approaches. In: Givnish TJ, Sytsma KJ Molecular evolution and adaptive radiation. Cambridge, Cambridge University Press. p. 1-54.

Google Earth Pro 7.3.2. 2019. Sites of study in the Pantanal, Corumbá, State of Mato Grosso do Sul, Brazil 19 30' 35.10" S 57 6' 7.05” W (site 1), 19³0'36.99" S 57 6' 9.56" W (site 2), elevation 9183 m, 3D map, imagery date 9 September 2011. http://earth.google.com/ web/. 26 Nov. 2019.

Gordon MS, Olson EC. 1994. Invasions of the land: the transitions of organisms from aquatic to terrestrial life. New York, Columbia University Press.

Gruntman M, Groß D, Májeková M, Tielbörger K. 2017. Decision-making in plants under competition. Nature Communications 8: 1-8.

Hamann U. 1998. Philydraceae. In: Kubitzki K (ed.) The families and genera of vascular plants. Flowering plants: Monocotyledons. Alismatanae and Commelinanae (except Gramineae). Vol. IV. Berlin, SpringerVerlag. p. 389-394.

Henry CP, Bornette G, Amoros C. 1994. Differential effects of floods on the aquatic vegetation of braided channels of the Rhone River. Journal of the North American Benthological Society 13: 439-467.

Johansen DA. 1940. Plant microtechnique. New York, Mc Graw-Hill Book Co.

Justin SHFW, Armstrong W. 1987. The anatomical characteristics of roots and plant response to soil flooding. New Phytologist 106: 465-495.

Luque R, Sousa HC, Kraus JE. 1996. Métodos de coloração de Roeser (1972) - modificado - e Kropp (1972) visando a substituição do azul de astra por azul de alcião 8GS ou 8GX. Acta Botanica Brasilica 10: 199-212.

Malavasi UC, Davis AS, Malavasi MM. 2016. Lignin in woody plants under water stress: a review. Floresta e Ambiente 23: 589-597.
Myburg AA, Lev-Yadun S, Sederoff R. 2013. Xylem structure and function. Chichester, John Wiley \& Sons Ltd.

O’Brien TP, Feder N, McCully ME. 1964. Polychromatic staining of plant cell walls by toluidine blue O. Protoplasma 59: 368-373.

Pannier F. 1960. Phisiological responses of Podostemaceae in their natural habitat. Internationale Revoe der Gesamten Hydrobiologie und Hydrogrgrafie 45: 347-354.

Pedralli G. 1992. Macrófitos aquáticos: Centro de diversidade. Ciência Hoje 14: 56-57.

Pellegrini MOO, Horn CN, Almeida RF. 2018. Total evidence phylogeny of Pontederiaceae (Commelinales) sheds light on the necessity of its recircumscription and synopsis of Pontederia L. PhytoKeys 108: 25-83.

Pott VJ, Pott A, Lima LCP, Moreira SN, Oliveira AKM. 2011. Aquatic macrophyte diversity of the Pantanal wetland and upper basin. Brazilian Journal of Botany 71: 255-263.

Pott VJ, Pott A. 1997. Checklist das macrófitas aquáticas do Pantanal, Brasil. Acta Botanica Brasilica 11: 215-227.

Pott VJ, Pott A. 2000. Plantas aquáticas do Pantanal. Corumbá, EMBRAPA.

Prado AL dos, Heckman CW, Martins FR. 1994. The seasonal succession of biotic communities in wetlands of the tropical wet-and-dry climatic zone: II. The aquatic macrophyte vegetation in the Pantanal of Mato Grosso, Brazil. Internationale Revue der Gesamten Hydrobiologie und Hydrographie 79: 569-589.

Richards JH, Lee DW. 1986. Light effects on leaf morphology in water hyacinth (Eichhornia crassipes). American Journal of Botany 73: 1741-1747.

Rodrigues S, Scremin-Dias E, Medeiros SCH, Souza MC. 2007. Alterações estruturais do caule e da folha de Ludwigia inclinata (L.f.) M. Goméz, desenvolvidos emersos e submersos no Pantanal Sul-Mato-Grossense. Revista Brasileira de Biociências 5: 174-176.

Ronzhina DA, P'yankov VI. 2001. Structure of the photosynthetic apparatus in leaves of Freshwater Hydrophytes: 2. Quantitative characterization of leaf mesophyll and the functional activity of leaves with different degrees of submersion. Russian Journal of Plant Physiology 48: 723-732.

Santana MAC, Catian G, Scremin-Dias E. 2019. Respostas morfológicas de Ludwigia helminthorrhiza (Mart.) H. Hara (Onagraceae) à sazonalidade hídrica do Pantanal. Oecologia Australis 23: 874-890.

Scremin-Dias E, Lorenz-Lemke AP, Oliveira AKM. 2011. The floristic heterogeneity of Pantanal and the occurrence of species with different adaptive strategies to water stress. Brazilian Journal of Biology 71: 275-282.

Scremin-Dias E, Pott VJ, Hora RC, Souza PR. 1999. Nos Jardins Submersos da Bodoquena: Guia para Identificação das Plantas Aquáticas de Bonito e Região. Campo Grande, Editora UFMS.

Scremin-Dias E. 1992. Morfoanatomia de órgãos vegetativos de Ludwigia sedoides (Humb. \& Bonpl.) Hara (Onagraceae) ocorrente no Pantanal Sul-Mato-Grossense. Msc Thesis. Universidade Federal do Paraná, Curitiba.

Scremin-Dias E. 2000a. A plasticidade fenotípica das macrófitas aquáticas em resposta à dinâmica ambiental. In: Cavalcanti TB, Walter BMT. (eds.) Tópicos Atuais em Botânica: Palestras convidadas do $51^{\circ}$ Congresso Nacional de Botânica. Brasília, EMBRAPA. p. 189-193.

Scremin-Dias E. 2000b. Estudo comparativo das espécies Echinodorus paniculatus Micheli e Echinodorus tenellus (Mart. ex Schult. \& Schult. f.) Buchenau, em períodos sucessivos de cheia e seca no Pantanal SulMato-Grossense. PhD Thesis, Instituto de Biociências da Universidade de São Paulo, São Paulo.

Scremin-Dias E. 2009. Tropical aquatic plants: morphoanatomical adaptations. In: Del-Claro K, Oliveira PS, Rico-Gray V. (eds.) Encyclopedia of Tropical Biology and Conservation Management. Paris, Encyclopedia of Life Support Systems - UNESCO/EOLSS. p. 84-132.

Sculthorpe CD. 1967. The biology of aquatic vascular plants. London, Eduard Arnold Publ.

Simpson MG. 1990. Phylogeny and classification of the Haemodoraceae. Annals of the Missouri Botanical Garden 77: 722-784. 
The aquatic species Pontederia azurea and P. crassipes (Pontederiaceae) in the Pantanal, Brazil: evidence of how plant structure can simultaneously reflect phylogeny and ecology

Simpson MG. 1998. Haemodoraceae. In: Kubitzki K. (ed.) The families and genera of vascular plants. Flowering plants: Monocotyledons. Alismatanae and Commelinanae (except Gramineae). Vol. IV. Berlin, Springer-Verlag. p. 212-128.

Sousa DJL, Scatena VL, Giulietti AM, Oriani A. 2016. Morphological and anatomical patterns in Pontederiaceae (Commelinales) and their evolutionary implications. Aquatic Botany 129: 19-30.

Sultan SE. 1995. Phenotypic plasticity and plant adaptation. Acta Botanica Neerlandica 44: 363-383.
Sultan SE. 2003. Phenotypic plasticity in plants: a case study in ecological development. Evolution \& Development 5: 25-33.

Thiers B. 2020, continuously updated. Index Herbariorum: a global directory of public herbaria and associated staff. New York Botanical Garden's Virtual Herbarium. http://sweetgum.nybg.org/science/ ih/. 20 Feb. 2020.

Yu H, Shen N, Yu D, Liu C. 2019. Clonal integration increases growth performance and expansion of Eichhornia crassipes in littoral zones: A simulation study. Environmental and Experimental Botany 159: 13-22. 